\title{
Loss of Soil Organic Matter, Lignocellulose and Microbial Population in Oil Palm Plantations Located at Different Slopes
}

\author{
Rika Andriati Sukma Dewi ${ }^{1}$, Lilik Tri Indriyati ${ }^{1}$, Bandung Sahari ${ }^{2}$ and Supiandi Sabiham ${ }^{1}$ \\ ${ }^{1}$ Department of Soil Science and Land Resources, Bogor Agricultural University, Jl. Meranti, \\ Kampus Dramaga, Bogor, Indonesia. ${ }^{2}$ PT. Astra Agro Lestari, Jl. Pulo Ayang Raya Blok OR \\ No. 1 Industry Area of Pulogadung Jakarta ${ }^{3}$, Indonesia, e-mail: rikaandriati_sukmadewi@yahoo.com
}

Received 09 February 2017/ accepted 28 April 2017

\begin{abstract}
Loss of soil organic matter can be caused by erosion triggered by soil compaction and high rainfall. The aims of the study were to determine (1) the loss of soil organic matter, lignocellulose, and soil microbial population due to erosion and (2) the contribution of organic matter from oil palm fronds. In the current study, the erosion plots were built on the accessible inter-row (gawangan hidup) and inaccessible inter-row (gawangan mati) of oil palm plantations located at the slope of 6-10\% and $>10 \%$. Soil organic matter, lignin, cellulose, and hemicellulose contents and total soil microbial populations were measured in the sediments collected from the erosion plots. The results showed that the loss of organic matter was higher in the accessible inter-row than that in the inaccessible inter-row. The addition of lignin, cellulose, and hemicellulose from oil palm fronds into the soil are $2.06 \mathrm{Mg} \mathrm{ha}^{-1} \mathrm{yr}^{-1}, 1.13 \mathrm{Mg}$ $\mathrm{ha}^{-1} \mathrm{yr}^{-1}$ and $1.02 \mathrm{Mg} \mathrm{ha}^{-1} \mathrm{yr}^{-1}$, respectively. Total bacterial population in the sediments taken from the accessible inter-row was higher than that from the inaccessible inter-row, while the total fungal population in the sediments from the inaccessible inter-row was higher than that from the accessible inter-row.
\end{abstract}

Keywords: Accessible inter-row, inaccessible inter-row, erosion, organic matter

\begin{abstract}
ABSTRAK
Kehilangan bahan organik tanah dapat disebabkan oleh erosi yang diperpercepat oleh pemadatan tanah dan curah hujan yang tinggi. Tujuan dari penelitian ini adalah untuk menentukan (1) kehilangan bahan organik, lignoselulosa, dan populasi mikroba tanah yang disebabkan oleh erosi dan (2) penambahan bahan organik dari pelepah daun kelapa sawit. Pada penelitian ini, plot erosi dibuat pada masing-masing gawangan yaitu gawangan hidup dan gawangan mati pada perkebuna kelapa sawit yang terletak pada kemiringan lereng 6-10\% dan >10\%. Parameterparameter yang diamati pada penelitian ini antara lain kandungan bahan organik, lignin, selulosa, hemiselulosa dan total populasi mikroba tanah pada sedimen yang terangkut. Hasil penelitian menunjukkan bahwa kehilangan bahan organik tanah lebih tinggi pada gawangan hidup dibandingkan pada gawangan mati. Penambahan lignin, selulosa, dan hemiselulosa dari pelepah daun kelapa sawit ke dalam tanah berturut-turut adalah $2.06 \mathrm{Mg} \mathrm{ha}^{-1}$ per tahun, 1.13 $\mathrm{tMg} \mathrm{ha}^{-1}$ per tahun, dan $1.02 \mathrm{Mg} \mathrm{ha}^{-1}$ per tahun. Total bakteri pada sedimen yang terangkut lebih tinggi pada gawangan hidup daripada pada gawangan mati, sedangkan total fungi pada sedimen lebih tinggi pada gawangan mati daripada pada gawangan hidup.
\end{abstract}

Kata Kunci: Bahan organik, erosi, gawangan hidup, gawangan mati

\section{INTRODUCTION}

Indonesia is the largest oil palm producer in the world with the potency of double production by 2030 (Gilbert 2012). The oil palm production of Indonesia in 2015 reached $31,284,300$ tons with the

J Trop Soils, Vol. 22, No. 3, 2017: 175-181

ISSN 0852-257X amount of planted area of 11,300,370 ha. Jambi province is one of the areas of oil palm suppliers in Indonesia with the production amounted to 947,048 tons and the planted area of 730,514 ha in 2015 (Ditjen Perkebunan 2015).

Oil palm is usually cultivated in high rainfall areas with an average annual rainfall of 2,339 $\mathrm{mm}$ (Wigena et al. 2009). However, high rainfall can cause the loss of soil organic matter through erosion, which further affects the productivity of oil palm. A 
previous study showed that oil palm production may decrease with the decrease of soil organic matter content (Hossain 2001). Organic matter plays crucial roles on the physical, chemical and biological properties of soil. On soil physical properties, organic matter plays roles to support the aggregate stability, infiltration, percolation, and water retention. On soil chemical properties, organic matter can increase cation exchange capacity, soil buffer capacity, and nutrient supply, whereas its effects on soil biology are associated with the increase of activity and diversity of soil organisms (Du Preez et al. 2011).

Oil palm plantation management involves the process of making the accessible inter-row and inaccessible inter-row. Accessible inter-row is an alley made for plantation activities such as harvesting and nurturing of oil palm plants that often passed by agricultural machinery and used as a tread. Such activities can lead to soil compaction. Further, soil compaction can cause soil erosion due to low soil porosity (Turner and Gillbanks 2003) and less number of understory cover crops. Meanwhile, inaccessible inter-row is a place of accumulation of organic matter such as oil palm fronds, in which one of the plantation management activities is pruning of oil palm fronds. The number of pruned fronds during the harvesting period is 1,125 fronds $\mathrm{ha}^{-1} \mathrm{yr}^{-1}$ and 3,036 fronds $\mathrm{ha}^{-1} \mathrm{yr}^{-1}$ during the nurturing period of oil palm plants, then the number of fronds (fresh weight) donated to the soil is about 4,160 fronds ha${ }^{1} \mathrm{yr}^{-1}$. Therefore, returning organic materials to the soil is expected to reduce soil organic matter loss due to erosion.

Considering the problems, it is needed to conduct a research to measure the magnitude of erosion, change of soil organic matter content in sediments, and total soil microbial populations (bacteria and fungi) based on differences in alley and slopes, as well as to calculate the organic material contributions obtained from pruning of oil palm fronds.

\section{MATERIALS AND METHODS}

Field observation was conducted in oil palm plantation areas in Bukit Suban Village, Hitam Ulu Subdistrict, Sarolangun District, Jambi Province, Indonesia. Sediment/soil and plant sample analyses were conducted at Soil Chemistry and Soil Fertility Laboratory, and Soil Biotechnology Laboratory of Bogor Agricultural University (IPB). Field observation was conducted in November 2015 until November 2016, while the sediment/soil and plant sample analyses were carried out in February 2016 until February 2017.
A set of erosion measurement tools for each erosion plot, a set of instruments for measuring organic-C, hemicellulose, cellulose and lignin contents in sediment and plant samples, and a set of tools for measuring total soil microbial populations were used. The materials used in this study were samples of oil palm fronds and sediments, and reagents for measuring organic- $\mathrm{C}$, hemicellulose, cellulose and lignin contents in the oil palm frond and sediment samples, and reagents for measuring total microbial populations in sediments.

\section{Experimental Design and Sediment Sampling}

Sediment sampling was carried out by considering two factors, namely (1) inter-row (gawangan) consisting of accessible inter-row and inaccessible inter-row, and (2) slopes consisting of $6-10 \%$ and $>10 \%$. Each inter-row and slope were plotted with 2 replications, therefore there were 8 erosion plots. The size of the erosion plot was $3 \mathrm{~m} \mathrm{x}$ $12 \mathrm{~m}$. Sampling of sediments from each erosion plot was done six times a year with a two-month interval. Sediment samples were composited from weekly sampling to a single sediment sample for each twomonth period.

The sampling of sediments to determine the total soil microbial populations (bacteria and fungi) was carried out in February 2016 from eight erosion plots. Furthermore, sediment samples were stored in the cool box in order to let the microbes to be dormant.

\section{Determination of Organic Matter Contribution from Oil Palm Fronds}

To find out the contribution of organic matter from oil palm fronds, the sampling of oil palm fronds was conducted. The oil palm fronds were taken from 15 trees (12\% of the total population of oil palm trees per ha, i.e. 125 trees) in five lanes of plants in which each lane consisted of three trees. Samples of the fresh fronds were taken from the fronds number 17 ( $17^{\text {th }}$ frond). The base, middle and the end part of each frond were then compiled to be a plant sample. Subsequently, the contents of organic$\mathrm{C}$, hemicellulose, cellulose, and lignin in each sample were then converted into acres, then the contribution of organic matter from oil palm plantations per hectare was calculated.

\section{Measurements of Organic Matter and Lignocellulose Contents and Total Soil Microbial Populations}

The organic-C contents in the sediments were measured using Walkey and Black method, whereas 
the organic-C content in the oil palm frond samples were measured using dried ash method.

The lignocellulose contents in the sediments and oil palm fronds were measured using the modified Lignin Klason Method (Dence 1992). The principle of this method is to obtain lignin deposits using $72 \%$ sulfuric acid.

Measurement of total soil microbial population was conducted based on the methodology proposed by Saraswati et al. (2007). The Nutrient Agar (NA) medium was used to determine the total bacterial population with $10^{-5}$ and $10^{-6}$ dilutions, while Potato Dextrose Agar (PDA) medium was used to determine the total fungal population with $10^{-3}$ and $10^{-4}$ dilutions. The method used was the pour plate method.

\section{Data Analysis}

The data from whole measurements were analyzed using MS Excel 2013 software and the the correlation analysis between parameters was conducted using SPSS 22 software.

\section{RESULTS AND DISCUSSION}

\section{The Amounts of Erosion in Oil Palm Plantation}

The results showed that the amount of sediment carried downstream was higher in the accessible inter-row $\left(7.00 \mathrm{Mg} \mathrm{ha}^{-1} \mathrm{yr}^{-1}\right)$ than that in the inaccessible inter-row (1.32 $\mathrm{Mg} \mathrm{ha}^{-1} \mathrm{yr}^{-1}$ ) (Figure 1). Moreover, the soil in the accessible inter-row was more compacted than that in the inaccessible inter-row. This might be due to the use of the accessible inter-row as an alley that was intensively traveled by agricultural machinery, causing high bulk density and low permeability (Table 1). The high bulk density and low permeability of the soil caused the surface runoff to be high. In contrast, the amount of sediment in the inaccessible inter-row was lower than that in the accessible inter-row. The small amount of transported soil materials through erosion was probably caused by the low bulk density and the high permeability of the soil, thereby resulting in the high amount of water infiltrated to the soil than flowed as surface runoff. The inaccessible interrow has contributed to the reduction on the amount

Table 1. Bulk density and permeability of soil in the accessible and inaccessible inter-rows.

\begin{tabular}{llcc}
\hline Slope & \multicolumn{1}{c}{ Alley } & $\begin{array}{c}\text { Bulk Density } \\
\left(\mathrm{g} \mathrm{cm}^{-3}\right)\end{array}$ & $\begin{array}{c}\text { Permeability } \\
\left(\mathrm{cm} \mathrm{h}^{-1}\right)\end{array}$ \\
\hline $10 \%$ & Accessible inter-row & 1.00 & 1.28 \\
& Inaccessible inter-row & 0.84 & 3.86 \\
\hline$>10 \%$ & Accessible inter-row & 1.02 & 0.77 \\
& Inaccessible inter-row & 0.83 & 3.40 \\
\hline
\end{tabular}

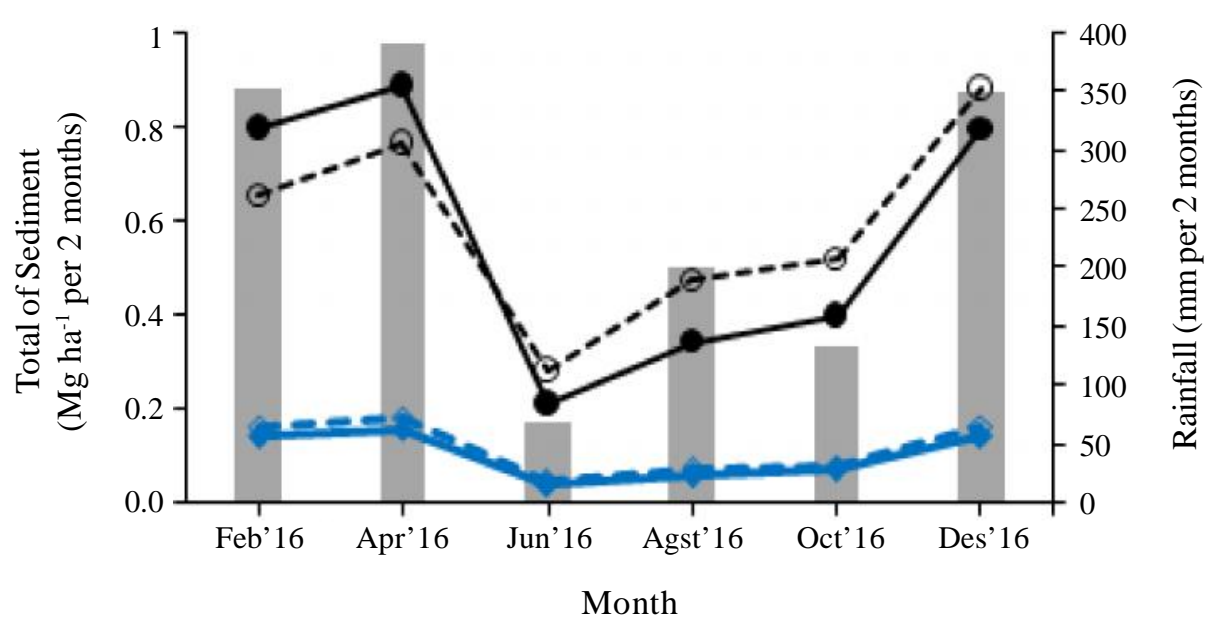

Figure 1. Bimonthly rainfall in oil palm plantation in Bukit Suban Village, Jambi Province and the amount of sediment per 2 months in accessible inter-row (AI) and inaccessible inter-row (II). : Rainfall,

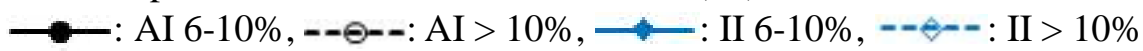


of soil transported by erosion. Organic matter in the form of oil palm fronds that were placed on the inaccessible inter-row and the presence of understory crops might prevent soil transport and improve soil structure, which further led to the better infiltration and drainage. In addition, the presence of oil palm fronds has also reduced the splash erosion since they prevented rain drops falling directly to the soil surface.

Figure 1 shows that the highest rainfall occurred in April 2016, while the lowest rainfall occured in June 2016. The pattern of rainfall in each month is similar to the pattern of the amounts of sediments obtained from both the accessible and inaccessible inter-rows. This phenomenon is supported by the high correlation between rainfall and the amount of sediment with the $r>0.90$. The study of Dai et al. (2017) showed that the increase of precipitation intensity in Huaxi District, Guizhou province of China has led to the increase of the amount of surface runoff, in which precipitation intensity that causes the surface runoff ranges from 0.8 up to $1.3 \mathrm{~mm}$ $\min ^{-1}$.

The slopes of the accessible inter-row affected the amount of transported soil during the erosion. The total sediment loaded on the slope of $>10 \%$ was $3.57 \mathrm{Mg} \mathrm{ha}^{-1} \mathrm{yr}^{-1}$, which was higher than that on the slopes of 6-10\% (3.43 Mg ha-1 $\left.\mathrm{yr}^{-1}\right)$. The high amount of transported soil on the slope of $>10 \%$ might be caused by soil's ability to percolate water through the soil pore, in which the percolation at the slope of $>10 \%$ is smaller $\left(0.77 \mathrm{~cm} \mathrm{~h}^{-1}\right)$ than that at the slope of $6-10 \%\left(1.28 \mathrm{~cm} \mathrm{~h}^{-1)}\right.$ (Table 1).
Meanwhile in February and April, when the pruning of understory crops has not been performed, the amount of sediment on the slope of $>10 \%$ was lower than that on the slopes of 6-10\%. It is due to the land at the slope of $>10 \%$ was densely covered by understory crops because the plots were sunexposed, whereas the land at the slopes of $6-10 \%$ was less densely covered by understory crops since the plot was under the shade. In the inaccessible inter-row, the slopes did not affect the amount of soil transported by erosion. This is because of the presence of organic matterials and cover crops that led to the low bulk density and high soil permeability (Table 1), so that more water was percolated into the soil than flowed as surface runoff.

\section{Changes of Soil Organic Matter and Soil Lignocellulose Contents}

The amount of soil organic matter in the accessible inter-row was higher than that in the inaccessible inter-row. In contrast, the total loss of soil organic matter in the accessible inter-row was $0.67 \mathrm{Mg} \mathrm{ha}^{-1} \mathrm{yr}^{-1}$, while that was $0.17 \mathrm{Mg} \mathrm{ha}^{-1} \mathrm{yr}^{-1}$ in the inaccessible inter-row. The high loss of soil organic matter through erosion in the accessible inter-row is proved by the significant correlation between the amount of sediment and the organic matter content in the sediment, with the correlation cofficient (r) around 0.54 at $1 \%$ significance level. The results indicated that the soil material transported through erosion in the accessible inter-row contained a lot of soil organic matter, resulting in the decrease

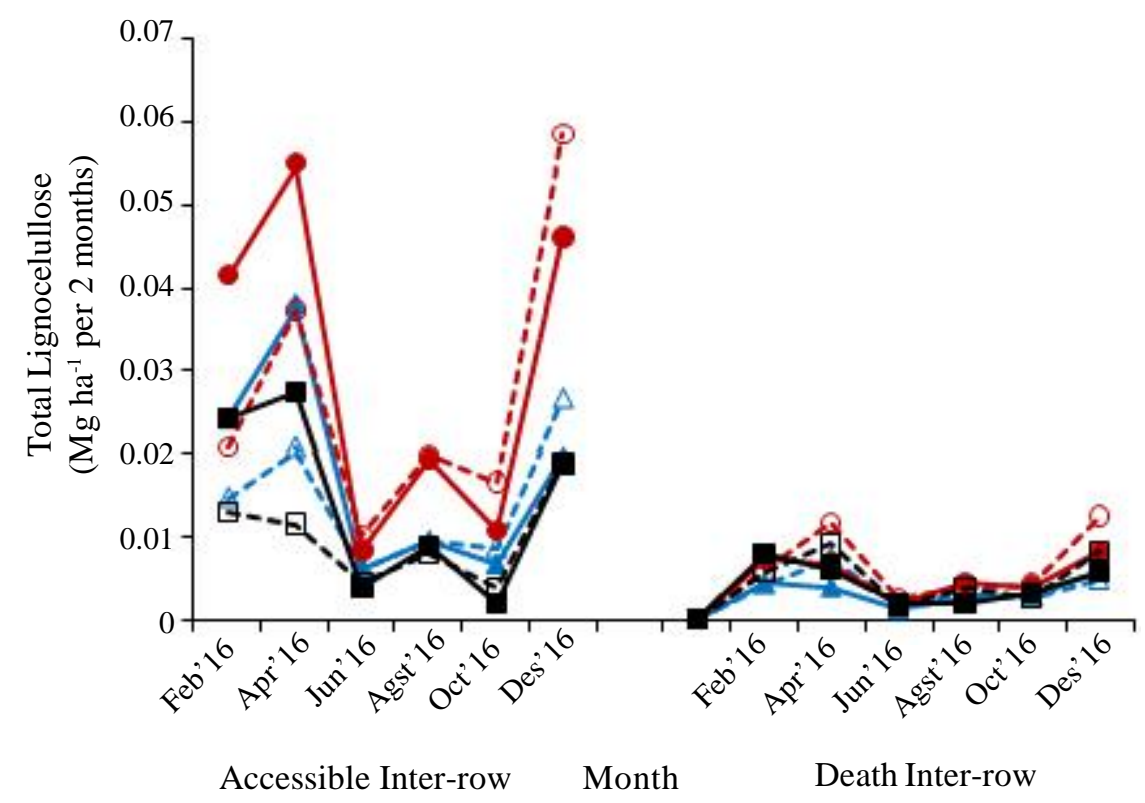

Figure 2. Organic matter and lignocellulose contents in the sediments, Hc: hemicellulose, C: cellulose, and

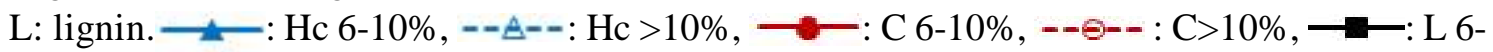
$10 \%,--\boxminus--:$ L $>10 \%$. 
of organic matter content in the soil layer. However, the loss of soil organic matter measured in the current study is still low compared to that in the study of Henson's (1999) in which the total loss of soil organic matter in the oil palm plantations at $0-45 \mathrm{~cm}$ depth reached $3.83 \mathrm{Mg} \mathrm{ha}^{-1}(710 \mathrm{~kg}$ $\mathrm{ha}^{-1} / 5.4$ years). The amount of sediment in the inaccessible inter-row is not correlated to the organic matter content in the sediment, so the erosion occurred in the inaccessible inter-row did not affect the total loss of soil organic matter.

In addition, Figure 2 shows that the total loss of lignocellulose in the accessible inter-row was higher than that in the inaccessible inter-row. Total hemicellulose, cellulose, and lignin contents in the sediments taken from accessible inter-row were 0.19 ; 0.34 ; and $0.14 \mathrm{Mg} \mathrm{ha}^{-1} \mathrm{yr}^{-1}$, respectively, whereas the total hemicellulose, cellulose, and lignin contents in the sediments from inaccessible interrow were $0.05 ; 0.07$; and $0.06 \mathrm{Mg} \mathrm{ha}^{-1} \mathrm{yr}^{-1}$, respectively.

Further, the correlation cofficients ( $r$ ) between the amount of sediment and hemicellulose, cellulose, and lignin contents in the sediments taken from the accessible inter-row are 0.42 (significant at 5\% siginifance level), 0.60 (significant at $1 \%$ siginifance level), and 0.41 (significant at 5\% siginifance level), respectively. On the other hand, there is no correlation between the amount of sediment and the lignocellulose content in the sediments taken from inaccessible inter-row. The total loss of cellulose and hemicellulose were higher than the loss of lignin in both accessible and inaccessible inter-rows. The result suggested that cellulose and hemicellulose are easier to be transported through erosion than lignin because both cellulose and hemicellulose degrade faster than lignin in soil. The high loss of cellulose both in the accessible and inaccessible inter-rows has decreased soil aggregate function. Soils with good structure can provide good water supply and adequate nutrients for plants, and organic matter plays an important role in improving soil structure. According to the study of Tan (2011), organic matter in the form of polysaccharide is able to improve soil aggregates by forming bonds with soil particles, resulting in better soil structure. The study of Tisdall and Oades (1982) also indicated that organic matter can stabilize soil aggregates by forming bonds with mineral materials.

The total loss of soil organic matter in the accessible inter-row with a slope of $>10 \%$ was 0.46 $\mathrm{Mg} \mathrm{ha}{ }^{-1} \mathrm{yr}^{-1}$, which was higher than that in the accessible inter-row with a slope of 6-10\% (i.e. 0.43 $\left.\mathrm{Mg} \mathrm{ha}{ }^{-1} \mathrm{yr}^{-1}\right)$. The result indicated that the slope affects the amount of transported soil through erosion in the accessible inter-row. However, the amounts of sediments at the slope of 6-10\% taken in February and April were higher than that at the slope of $>$ $10 \%$. This is because the understory crops grew densely at the slope of $>10 \%$ due to the plot was exposed to sunlight, whereas the plot with the slope of $6-10 \%$ was under the shade.

\section{Total Microbial Populations in Sediments}

Organic matter is the source of energy for both macroorganism and microorganism in soil. Therefore, sufficient amount of organic matter in soil is one of the factors that determines the growth and development of microbes (Anas et al. 1997). Improvement of soil physical and chemical properties by organic matter application might affect the life of soil organisms including the type and quantity of soil microbes. In addition, soil microbial biomass is closely related to soil organic matter content, and the soil organic matter content is strongly influenced by the addition of organic materials including plant residues to the soil (Franzluebbeers and Arshad 1997).

Table 2 generally shows that the total bacterial population in the sediments is higher than the total fungal population. The total soil bacteria measured in the sediments taken from the accessible interrow was higher than that from the inaccessible interrow. In contrast, the total fungal population obtained in the inaccessible inter-row was more numerous

Table 2. Total bacterial and fungal populations in the sediments sampled in February 2016.

\begin{tabular}{|c|c|c|c|c|}
\hline \multirow[b]{2}{*}{ Alley } & \multirow[b]{2}{*}{ Slope } & \multirow{2}{*}{$\begin{array}{l}\text { Amount of } \\
\text { Sediment } \\
\left(\mathrm{Mg} \mathrm{ha}^{-1}\right)\end{array}$} & \multicolumn{2}{|c|}{ Microbial Population (CFU) } \\
\hline & & & Bacteria $\left(10^{6}\right)$ & Fungi $\left(10^{3}\right)$ \\
\hline Accessible & $6-10 \%$ & 0.79 & 4.75 & 9.00 \\
\hline inter-row & $>10 \%$ & 0.65 & 5.87 & 13.25 \\
\hline Inaccessible & $6-10 \%$ & 0.14 & 3.85 & 14.50 \\
\hline inter-row & $>10 \%$ & 0.16 & 4.70 & 16.50 \\
\hline
\end{tabular}


Table 3. Organic matter and lignocellulose contents in the oil palm fronds.

\begin{tabular}{cccc}
\hline \multirow{2}{*}{$\begin{array}{c}\text { Organic Matter } \\
(\%)\end{array}$} & \multicolumn{3}{c}{ Content of Lignocellulose } \\
\cline { 2 - 4 } & Hemicellulose (\%) & Cellulose (\%) & Lignin (\%) \\
\hline 93.98 & 21.81 & 24.34 & 44.12 \\
\hline
\end{tabular}

than that in the accessible inter-row. Along with the erosion of organic matter, bacteria tend to be easily eroded than fungi because of their ability to produce hyphae. Furthermore, the higher total fungal population in the inaccessible inter-row than that in the accessible inter-row is due to the organic matter in the inaccessible inter-row is mainly present in the form of fresh organic matter and in general fungi involve in the early decomposition process of this organic matter. The study of Hidayati et al. (2005) indicated that fungi act to degrade complex organic matter into simple organic matter, such as organic acids, in which the temperature and $\mathrm{pH}$ at the beginning of the composting process are around 41$45^{\circ} \mathrm{C}$ and 6.8 , respectively. Subsequently, bacteria involve in the next process of organic matter decomposition. Table 2 shows that the number of bacteria and fungi both in the sediments taken from accessible and accessible inter-rows increases with the increase of slope of the land.

The erosion in both accessible inter-row and inaccessible inter-row further leads to the decrease of microbial population in the soil layer. The presence of microbes in soil will assist the biochemical processes of organic matter decomposition by producing enzymes, releasing nutrients for plants. In addition, microbes have a symbiotic relationship with plant roots that can enhance the development and stability of soil aggregates through the production of exudates, secondary metabolites and organic inputs, which act as adhesives between organic matter and soil particles. The increase of soil organic matter content is associated with the increase of microbial biomass and activity, producing cellular polysaccharides that play a role as soil binding agents (Wang et al. 2013).

\section{Contributions of Organic Matter and Lignocellulosic Compounds from Oil Palm Fronds}

Table 3 describes the contents of organic matter and lignocellulose in oil palm fronds, in which the content of lignin is higher (44.12\%) than the cellulose (24.34\%) and hemicellulose contents (21.81\%). The pruned oil palm fronds are usually placed in the inaccessible inter-row, which can then contribute organic matter and nutrients for soil and plants. The dry weight of oil palm fronds according to
Simanihuruk et al. (2008) is $4.5 \mathrm{~kg}$ with a moisture content of $75 \%$. In addition, the number of pruned fronds is about 4,160 fronds ha ${ }^{-1} \mathrm{yr}^{-1}$, so it can be estimated that the contribution of the dry weight of oil palm fronds in this study is $4.68 \mathrm{Mg} \mathrm{ha}^{-1} \mathrm{yr}^{-1}$.

Table 3 shows that the contributions of organic matter, lignin, cellulose, and hemicellulose from oil palm fronds were $4.39 \mathrm{Mg} \mathrm{ha}^{-1} \mathrm{yr}^{-1}, 2.06 \mathrm{Mg} \mathrm{ha}^{-1}$ $\mathrm{yr}^{-1}, 1.13 \mathrm{Mg} \mathrm{ha}^{-1} \mathrm{yr}^{-1}$, and $1.02 \mathrm{Mg} \mathrm{ha}^{-1} \mathrm{yr}^{-1}$ respectively. The total addition of the organic carbon from the pruned oil palm fronds was about $2.71 \mathrm{Mg}$ $\mathrm{ha}^{-1} \mathrm{yr}^{-1}$. This result is in contrast to that in the study of Henson's (1999), which showed that the addition of total carbon from pruned oil palm fronds in Johor, Malaysia is about 4.25 $\mathrm{Mg} \mathrm{ha}^{-1} \mathrm{yr}^{-1}$. The contribution of organic matter from oil palm fronds to the soil is potentially useful for improving the physical, chemical and biological properties of the soils, hence the loss of organic matter in oil palm plantations through erosion can be addressed.

\section{CONCLUSIONS}

The amount of erosion measured in the accessible inter-row is $7.00 \mathrm{Mg} \mathrm{ha}^{-1} \mathrm{yr}^{-1}$, which is higher than that in the inaccessible inter-row (i.e. 1.32 $\left.\mathrm{Mg} \mathrm{ha}^{-1} \mathrm{yr}^{-1}\right)$. The loss of soil organic matter in the accessible inter-row $\left(0.67 \mathrm{Mg} \mathrm{ha}^{-1} \mathrm{yr}^{-1}\right)$ is higher than that in the inaccessible inter-row $\left(0.17 \mathrm{Mg} \mathrm{ha}^{-1} \mathrm{yr}^{-1}\right)$. In addition, the total bacterial population in the sediments of oil palm plantations is higher than the total fungal population. Total bacterial population in the sediments taken from the accessible inter-row is higher than that from the inaccessible inter-row. In contrast, the total fungal population in the sediments taken from the inaccessible inter-row is higer than that from the accessible inter-row. The contributions of lignin, cellulose and hemicellulose from oil palm fronds are $2.06 \mathrm{Mg} \mathrm{ha}^{-1} \mathrm{yr}^{-1}, 1.13 \mathrm{Mg}$ $\mathrm{ha}^{-1} \mathrm{yr}^{-1}$ and $1.02 \mathrm{Mg} \mathrm{ha}^{-1} \mathrm{yr}^{-1}$, respectively.

\section{REFERENCES}

Anas I, DA Santosa and R Widyastuti. 1997. Use of microbiological features in evaluating soil degradation. In: H Subagyo, S Sabiham, R Shofiyati, AB Siswanto, F Agus, A Rachman and S Ropiq (eds). Prosiding Kongres Nasional VI HITI.Bogor (In Indonesian). 
Dai Q, X Peng, Z Yang and L Zhao. 2017. Runoff and erosion processes on bare slopes in the Karst Rocky desertification area. Catena 152: 218-226.

Dence CW. 1992. Determination of lignin.In Lin SY, Dence CW (eds). Method in Lignin Chemistry. SpringerVerlag. Berlin.

Ditjen Perkebunan. 2015. Statistic of Indonesia Plantation, Oil Palm Comodity 2014-2016. Direktotat Jendral Perkebunan. Jakarta (in Indonesian).

Du Preez CC, CW Van Huyssteen and PNS Mnkeni. 2011. Land use and soil organic matter in South Africa 2: A review on the influence of arable crop production. S Afr J Sci 107: 1-8.

Franzlueebbers AJ and MAArshad. 1997. Soil microbial biomass and mineralizable carbon of water stable aggregates. Soil Sci Soc Am J 61: 1090-1097.

Gilbert N. 2012. Palm-oil boom raises conservation concerns. Nature 487: 14-15. doi:http://dx.doi.org/ 10.1038/487014.

Henson IE. 1999. Comparative ecophysiology of oil palm and tropical rain forest. In: Gurmit S, Lim KH, Teo L, and Lee K (eds). Oil Palm and The Environment: A Malaysian Perspective. Malaysian Oil Palm Growers' Council. Kuala Lumpur : 9-39.

Hidayati YA, E Harlia, TB Benito and A Kurnani. 2005. Identification of fungi and bacteria in the process of composting sheep dung as supporting environmental sanitation. National Workshop on Food Safety of Livestock Products (in Indonesian).
Hossain J. 2001. Farmer's view on soil organic matter depletion and its management in Bangladesh. Nutr Cyc Agroecosys 61: 197-204.

Saraswati R, E Husen and RDM Simanungkalit. 2007. Enumeration of bacteria, fungi and actinomycetes. In: RD Hastuti and RCB Ginting (eds). Analysis Method of Soil Biology. Balai Besar Penelitian dan Pengembangan Sumberdaya Lahan Pertanian: Bogor Jawa Barat (in Indonesian).

Simanihuruk K, Junjungan and SP Ginting. 2008. Utilization of palm oil palm silage as feed of goat growth. National Seminar on Livestock and Veterinary Technology. Loka Goat Study Research. Sungai Putih (in Indonesian).

Tan KH. 2011. Principle of Soil Chemistry. CRC Press. London.

Tisdall JM and JM Oades. 1982. Organic matter and waterstable aggregates in soils. $J$ Soil Sci 3: 141-163.

Turner PD, Gillbanks RA. 2003. Oil Palm Cultivation and Management. Kuala Lumpur, Malaysia. The Incorporated Society of Planters.

Wang F, YA Tong, JS Zhang, PC Gao and JN Coffie. 2013. Effects of various organic matters on soil aggregate stability and soil microbiological properties on the Loess Plateau of China. Plant Soil Environ 4: 162-168.

Wigena IGP, Sudradjat, SRP Sitorus and H Siregar. 2009. Soil and climatic characteristics and suitability for plasma palm plantations in Sei Pagar, Kampar district, Riau province. J Tanah dan Iklim 30: 1-16 (in Indonesian). 